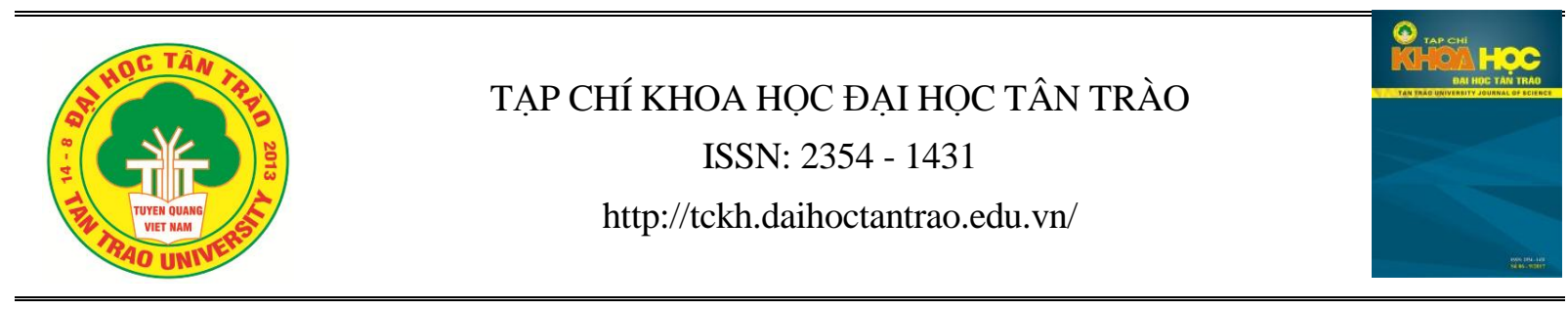

\title{
NGHIÊN CỨU ĐẶC ĐIỂM SINH HỌC, KHẢ NĂNG SẢN XUẤT VÀ HIỆU QUẢ KINH TẾ CỦA VỊT TRỜI NUÔI TẠI NINH BÌNH
}

\author{
Tù Quang Trung ${ }^{a^{*}}$, Lê Phuoong Dung ${ }^{a}$ \\ ${ }^{a}$ Đại học Su phạm Thái Nguyên \\ *Email: tuquangtrung@dhsptn.edu.vn
}

\section{Thông tin bài viết}

Ngày nhận bài:

28/2/2020

Ngày duyệt đăng:

$12 / 8 / 2020$

Tù khóa:

Đặc điểm sinh hoc, khả năng sản xuất, sinh trương, vịt tròi

\section{Tóm tắt}

Qua nghiên cứu cho thấy vịt trời nuôi tại nông hộ tỉnh Ninh Bình con non có lông màu nâu xám, lông cổ, lông ức màu vàng, lông phần lưng có chấm vàng, đầu có sọc vàng kéo xuống dưới, phần cổ và hai bên mắt có một vệt đen từ mắt kéo dài ra sau, chân có màu đen. Vịt non có tiếng kêu kéc kéc. Vịt trưởng thành tuổi có lông màu xám vằn, lông đuôi màu nâu đen có ánh và viền nâu nhạt, lông cánh ánh xanh, phần mỏ có màu đen, đầu mỏ có vành khuyết màu vàng. Con trống lông cổ dưới màu trắng, cổ có 2 sọc trắng, hai bên mắt có một vệt đen từ mắt kéo dài ra sau, lông đuôi vểnh, có vài lông cong, đầu to, mắt màu nâu sẫm. Vịt trống có tiếng kêu khẹc khẹc. Vịt mái lông đuôi thẳng, hơi cụp xuống, đầu nhỏ hơn con trống có mắt màu nâu nhạt. Vịt mái có tiếng kêu quạc quạc. Tỷ lệ nuôi sống đến 21 tuần tuổi là 98\%. Trọng lượng cơ thể lúc mới nở khoảng 42g. Giai đoạn 21 tuần tuổi bình quân con trống đạt 1.452,21 g/con, con mái đạt 1.264,92 g/con. Tiêu tốn thức ăn trung bình giai đoạn từ sơ sinh - 21 tuần tuổi của con trống là $7,43 \mathrm{~kg}$ và con mái là 8,07 $\mathrm{kg}$. Tỷ lệ thân thịt, tỷ lệ thịt đùi + thịt ngực của con trống và con mái lần lượt là $63,80-62,94 \%$ và $48,23-51,30 \%$.

\section{1. Đặt vấn đề}

Vịt trời là một giống vịt hoang dã với rất nhiều ưu điểm: sống trong tự nhiên, thịt thơm, chắc thịt, ngon, mềm hơn các loại vịt thông thường và đặc biệt là thịt không có mùi hôi, rất phù hợp với nhu cầu ẩm thực của người Việt Nam nên được khách hàng ưa chuộng và trở thành một đặc sản, trong bối cảnh người dân ngày càng "sành ăn" đồng thời đề cao cảnh giác với thực phẩm bẩn thì sản phẩm vịt trời ngon, sạch đang hút khách. Xuất phát từ nhu cầu về đặc sản vịt trời, tận dụng những điều kiện tự nhiên trong những năm gần đây việc thuần hóa vịt trời hoang dã và nuôi vịt trời thương phẩm đã được phát triển và nhân rộng ở nhiều tỉnh thành không những đã cải thiện được kinh tế hộ gia đình, vươn lên làm giàu mà còn góp phần làm đa dạng hóa giống vật nuôi ở nước ta. Đây là mô hình kinh tế mới, hiệu quả cao đã và đang được nhân rộng tại tỉnh Ninh Bình cũng như nhiều tỉnh thành khác và trở thành một nghề mới trong lĩnh vực chăn nuôi thủy cầm ở Việt Nam. Đã có rất nhiều công trình nghiên cứu về vịt trời nhưng chủ yếu là nghiên cứu về đặc điểm sinh trưởng và khả năng sinh sản còn chưa có công trình nào nghiên cứu một cách đầy đủ và có hệ thống về đặc điểm sinh học, khả năng sản xuất và hiệu quả kinh tế của vịt trời hoang dã đã được thuần hóa. Để đánh giá được khả năng sản xuất và hiệu quả kinh tế của vịt trời khi được thuần hóa và nuôi theo mô hình tập trung nhằm cung cấp thêm tài liệu cho người chăn nuôi, làm cơ sở cho việc giảng dạy nghiên cứu cũng như để bổ sung các dữ liệu về 
giống thủy cầm tự nhiên đã được thuần hóa trong điều kiện chăn nuôi tập trung chúng tôi tiến hành nghiên cứu đề tài: "Nghiên cúu đặc điểm sinh học, khả năng sản xuất và hiệu quả kinh tế của vịt tròi nuôi tại Ninh Bình".

\section{Nội dung và phương pháp nghiên cứu}

\subsection{Nội dung}

Xác định một số đặc điểm sinh học của vịt trời; Đánh giá sức sống, khả năng sản xuất của vịt trời trong điều kiện chăn nuôi tập trung tại trang trại và hiệu quả kinh tế của mô hình nuôi vịt trời tập trung tại trang trại.

\section{2. Đối tương, địa điểm và thời gian nghiên cứu}

Vịt trời từ sơ sinh - 21 tuần tuổi

Địa điểm: Trại vịt thịt, thị trấn Yên Thịnh, huyện Yên Mô, tỉnh Ninh Bình

Thời gian: Từ tháng 3/2019 đến 01/2020

\subsection{Phương pháp nghiên cúu}

Thí nghiệm được thực hiện với 180 vịt trời từ so sinh - 21 tuần tuổi, chia đều làm 2 lô trống và mái, mỗi lô được chia thành 9 nhóm, mỗi nhóm có 10 $\operatorname{con}(9 \times 10=90)$.

Chế độ dinh dưỡng là thức ăn hỗn hợp vịt thịt của Công ty cổ phần Dinh dưỡng Hồng Hà trong $1 \mathrm{~kg}$ có chứa $3000 \mathrm{Kcal} \mathrm{ME}$, tỷ lệ protein thô là $15 \%$, xơ thô $6 \%$, lysine $0,8 \%$, Methionine + Cystine 0,5\%.

Các chỉ tiêu theo dõi theo phương pháp thông dụng nghiên cứu về chăn nuôi bao gồm:

- Các chỉ tiêu về đặc điểm sinh học: Màu sắc bộ lông lúc 1 ngày tuổi và 21 tuần tuổi, hình thái cơ thể, tiếng kêu.

- Khả năng sinh trưởng, khả năng chuyển hóa thức ăn và năng suất thịt.

- Hạch toán kinh tế nuôi vịt thịt.

\section{Kết quả nghiên cứu và thảo luận}

\section{1. Đắc điểm sinh hoc của vịt trò̀i}

Kết quả quan sát đặc điểm sinh học của vịt trời nuôi tại tỉnh Ninh Bình như sau:

Vịt mái 1 ngày tuổi: Màu lông nâu xám, phần cổ và ức có màu lông vàng, lưng có 4 chấm màu vàng đặc trưng. Đầu cổ thon gọn, hai bên mắt có một vệt đen từ mắt kéo dài ra sau, Chân màu đen, thô to, tiếng kêu kéc kéc.
Vịt trống 1 ngày tuổi: Màu lông nâu xám, phần cổ và ức có màu lông vàng, lưng có 4 chấm màu vàng đặc trưng. Đầu cổ to thô, hai bên mắt có một vệt đen từ mắt kéo dài ra sau, chân màu đen, nhỏ nhắn, Tiếng kêu kéc kéc.

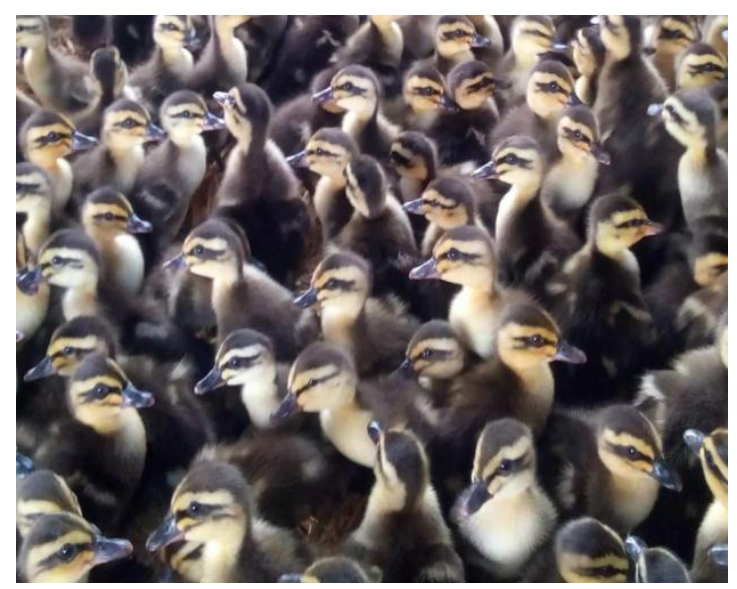

Hình 3.1. Vịt 1 ngày tuổi

Vịt mái trưởng thành: Màu lông xám vằn, lông bao cánh nhỏ và bao cánh nhỡ màu xám, lông bao cánh lớn màu xám chì với một dải vằn gần cuối lông trắng và một vằn đen ở mút, xen lẫn lông màu ánh xanh, lông đuôi nâu đen có ánh viền nâu nhạt, lông đuôi thẳng và hơi cụp xuống, phần đầu và cổ có 2 sọc dài màu trắng, hai bên mắt có một vệt đen kéo dài ra sau, mắt tròn màu nâu nhạt, mỏ màu đen, điểm đầu mỏ có vành khuyết màu vàng, chân màu đỏ. Vịt mái có thân hình cân đối, săn chắc, ít mỡ, ngực sâu, lườn phẳng, phía lỗ huyệt

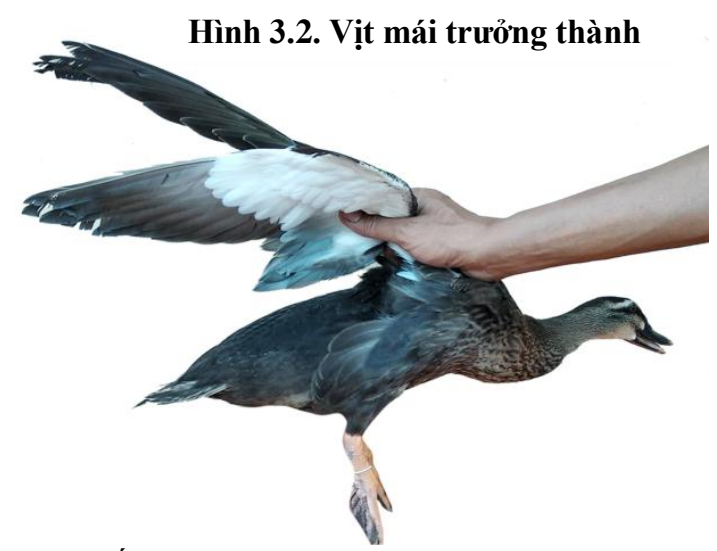

rộng và tiếng kêu quạc quạc.

Vịt trống truởng thành: Màu xám vằn, lông bao cánh nhỏ và cánh nhỡ có màu xám, lông bao cánh lớn màu xám chì với một dải vằn gần cuối lông trắng và một vằn đen ở mút, xen lẫn lông màu ánh xanh, lông đuôi nâu đen có ánh viền nâu nhạt, lông đuôi vểnh lên và có vài lông cong, cổ có 2 sọc dài màu trắng, hai mắt có một vệt đen kéo dài ra sau, mắt tròn màu nâu sẫm, mỏ màu đen, điểm đầu mỏ có vành khuyết màu vàng, 
chân màu đỏ. Vịt trống có đầu to, thân hình cân đối, săn chắc, ít mõ̃, ngực sâu, lườn phẳng, phía lỗ huyệt nhỏ gọn và tiếng kêu khẹt khẹt.

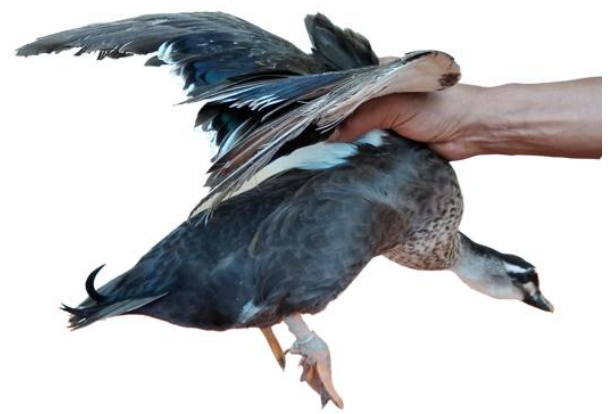

Hình 3.3. Vịt trống trưởng thành

3.2. Tỷ lệ nuôi sống và khả năng sinh trưởng của vịt trò̀i

3.2.1. Tỷ lệ nuôi sống của vịt trời

Kết thúc 21 tuần tuổi tỷ lệ nuôi sống của vịt trời đạt trên $98 \%$. kết quả tỷ lệ nuôi sống của vịt trời cao hơn so với 1 số giống vịt trước đó như: Nghiên cứu Nguyễn Văn Ban (2000) thì vịt Cỏ trắng có tỷ lệ nuôi sống 20 tuần tuổi là 95,09\%; Nguyễn Đức Trọng và cs (2010) cho biết con lai giữa vịt Triết Giang và Cỏ có tỷ lệ nuôi sống trung bình 94,74 - 98,95 \% hay theo Nguyễn Đức Cường (2017) tỷ lệ nuôi sống của vịt trời đến 24 tuần tuổi đạt cao, cụ thể Vịt mái đạt 94,67\%; Vịt đực đạt $88 \%$. Điều này chứng tỏ vịt trời là loài động vật hoang dã có sức đề kháng tốt, thích nghi với điều kiện khí hậu Việt Nam và hoạt động nuôi nhốt của con người.

\subsubsection{Sinh truởng tích lũy của vịt trời}

Vịt trời được cân khối lượng hàng tuần để xác định sinh trưởng tích lũy qua từng giai đoạn, sau đây là khối lượng trung bình của vịt ở các giai đoạn tuổi.

Bảng 3.1: Khối lượng của vịt trời qua các tuần tuổi (g/con/ngày) $(\mathrm{n}=180)$

\begin{tabular}{ccccc}
\hline \multirow{2}{*}{ Tuần tuổi } & \multicolumn{2}{c}{ Trống } & \multicolumn{2}{c}{ Mái } \\
\cline { 2 - 5 } & $\overline{\boldsymbol{x}}_{ \pm \boldsymbol{m}} \boldsymbol{m} \overline{\boldsymbol{x}}$ & Cv\% & $\overline{\boldsymbol{x}}_{ \pm \boldsymbol{m}} \boldsymbol{\boldsymbol { x }}$ & Cv\% \\
\hline sơ sinh & $43,45 \pm 0,00$ & 0,02 & $40,55 \pm 0,01$ & 0,03 \\
3 & $277,62 \pm 0,58$ & 0,36 & $261,10 \pm 0,88$ & 0,27 \\
6 & $577,34 \pm 1,10$ & 0,37 & $534,94 \pm 1,11$ & 0,41 \\
9 & $866,93 \pm 1,62$ & 0,45 & $772,88 \pm 1,76$ & 0,76 \\
12 & $1102,01 \pm 2,70$ & 0,65 & $942,52 \pm 2,69$ & 0,89 \\
15 & $1261,44 \pm 3,76$ & 0,71 & $1087,89 \pm 3,66$ & 1,06 \\
18 & $1390,03 \pm 4,45$ & 0,76 & $1211,09 \pm 4,07$ & 1,01 \\
21 & $1452,21 \pm 4,65$ & 0,73 & $1264,92 \pm 4,54$ & 1,03 \\
\hline
\end{tabular}

Kết quả bảng 3.1 cho thấy khối lượng của vịt thí nghiệm tăng dần theo các tuần tuổi. Giai đoạn sơ sinh khối lượng của vịt trống và vịt mái tương ứng là 43,45 và 40,55 g/con. Đến kết thúc 21 tuần tuổi khối lượng vịt trống và vịt mái tương ứng là 1452,21 và $1264,92 \mathrm{~g} / \mathrm{con}$. So với nghiên cứu của Nguyễn Đức Cường (2017) với khối lượng vịt trời “Anas Supercillosa” ở 24 tuần tuổi đạt 1152 g/con và so với nghiên cứu của Nguyễn Thị Minh và cs (2007) với khối lượng vịt Cỏ C1 có khối lượng lúc 21 tuần tuổi là $1195,8-1250,0 \mathrm{~g} / \mathrm{con}$ thì kết quả của chúng tôi cao hơn.

\subsubsection{Sinh trương tuyệt đối của vịt trò̀i}

Kết quả theo dõi sinh trưởng tuyệt đối của vịt thịt thí nghiệm qua các giai đoạn tuần tuổi được thể hiện ở bảng 3.2 .

Bảng 3.2. Sinh trưởng tuyệt đối của vịt trời qua các tuần tuổi $(\mathrm{g} / \mathrm{con} / \mathrm{ngày})(\mathrm{n}=180)$

\begin{tabular}{ccccc}
\hline \multirow{2}{*}{ Tuần tuổi } & \multicolumn{2}{c}{ Trống } & \multicolumn{2}{c}{ Mái } \\
\cline { 2 - 5 } & $\overline{\boldsymbol{x}}_{ \pm} \boldsymbol{m} \overline{\boldsymbol{x}}$ & $\mathbf{C v} \%$ & $\overline{\boldsymbol{x}}_{ \pm} \boldsymbol{m} \overline{\boldsymbol{x}}$ & Cv\% \\
\hline Sơ sinh -3 & $11,15 \pm 0,03$ & 0,42 & $10,50 \pm 0,05$ & 0,43 \\
$3-6$ & $14,27 \pm 0,05$ & 0,57 & $13,04 \pm 0,06$ & 0,69 \\
$6-9$ & $13,79 \pm 0,69$ & 1,20 & $11,33 \pm 0,65$ & 1,21
\end{tabular}




\begin{tabular}{ccccc}
\hline \multirow{2}{*}{ Tuần tuổi } & \multicolumn{2}{c}{ Trống } & \multicolumn{2}{c}{ Mái } \\
\cline { 2 - 5 } & $\overline{\boldsymbol{x}}_{ \pm} \boldsymbol{m} \overline{\boldsymbol{x}}$ & $\mathbf{C v} \%$ & $\overline{\boldsymbol{x}}_{ \pm} \boldsymbol{m} \overline{\boldsymbol{x}}$ & Cv\% \\
\hline $9-12$ & $11,19 \pm 0,60$ & 1,82 & $8,08 \pm 0,62$ & 1,80 \\
$12-15$ & $7,59 \pm 0,66$ & 2,38 & $6,92 \pm 0,61$ & 2,10 \\
$15-18$ & $6,12 \pm 0,65$ & 2,50 & $5,87 \pm 0,67$ & 2,12 \\
$18-21$ & $2,96 \pm 0,62$ & 2,96 & $2,56 \pm 0,73$ & 2,42 \\
So sinh $-\mathbf{2 1}$ & $\mathbf{9 , 5 8} \pm \mathbf{0 , 0 2}$ & $\mathbf{1 , 0 4}$ & $\mathbf{8 , 3 3} \pm \mathbf{0 , 0 5}$ & $\mathbf{1 , 0 8}$ \\
\hline
\end{tabular}

Kết quả bảng 3.2 cho thấy tốc độ sinh trưởng của vịt trống cao hơn so với vịt mái. Tuy nhiên, vịt trống và vịt mái đều phù hợp với quy luật sinh trưởng phát dục theo giai đoạn của vịt. Ở giai đoạn sơ sinh - 3 tuần tuổi sinh trưởng tuyệt đối của vịt trống là $11,15 \mathrm{~g} / \mathrm{con} / \mathrm{ngày}$, của vịt mái là $10,50 \mathrm{~g} / \mathrm{con} /$ ngày. Đến giai đoạn từ $3-12$ tuần tuổi sinh trưởng tuyệt đối của cả vịt trống và vịt mái đều cao. Bắt đầu giai đoạn từ $12-15$ tuần tuổi vịt lúc này đang thay lông sinh trưởng có xu hướng giảm mạnh (vịt trống là 7,59 $\mathrm{g} / \mathrm{con} /$ ngày của vịt mái là $6.92 \mathrm{~g} / \mathrm{con} /$ ngày). Kết quả sinh trưởng tuyệt đối trung bình (từ sơ sinh - 21 tuần tuổi) của vịt trống là $9,58 \mathrm{~g} / \mathrm{con} /$ ngày và của vịt mái là $8,33 \mathrm{~g} / \mathrm{con} /$ ngày.

\subsection{Khả năng sử dụng và chuyển hóa thức ăn của vịt trò̀i}

\subsubsection{Khả năng thu nhận thức ăn của vịt trời}

Kết quả về khả năng tiêu thụ thức ăn của vịt trời thí nghiệm qua các tuần tuổi được thể hiện ở bảng 3.3.

Bảng 3.3. Lượng thức ăn thu nhận của vịt trời qua các tuần tuổi $(\mathrm{g} / \mathrm{con} / \mathrm{ngày})(\mathrm{n}=180)$

\begin{tabular}{ccccc}
\hline \multirow{2}{*}{ Tuần tuổi } & \multicolumn{2}{c}{ Trống } & \multicolumn{2}{c}{ Mái } \\
\cline { 2 - 5 } & $\overline{\boldsymbol{x}}_{ \pm \boldsymbol{m}} \boldsymbol{m} \overline{\boldsymbol{X}}$ & $\mathbf{C v \%}$ & $\overline{\boldsymbol{x}}_{ \pm \boldsymbol{m}} \overline{\boldsymbol{x}}$ & $\mathbf{C v \%}$ \\
\hline Sơ sinh - 3 & $27,10 \pm 0,02$ & 0,07 & $26,01 \pm 0,03$ & 0,05 \\
$3-6$ & $54,98 \pm 0,18$ & 0,62 & $52,59 \pm 0,26$ & 0,53 \\
$6-9$ & $75,65 \pm 0,51$ & 1,21 & $72,64 \pm 0,60$ & 1,31 \\
$9-12$ & $81,05 \pm 0,60$ & 1,24 & $76,98 \pm 0,76$ & 1,21 \\
$12-15$ & $82,74 \pm 0,67$ & 1,65 & $77,13 \pm 0,83$ & 0,72 \\
$15-18$ & $85,82 \pm 0,89$ & 1,97 & $80,57 \pm 0,77$ & 0,74 \\
$18-21$ & $92,17 \pm 0,94$ & 1,83 & $84,67 \pm 0,81$ & 0,80 \\
So $\sinh -\mathbf{2 1}$ & $\mathbf{7 1 , 2 2} \pm \mathbf{0 , 2 3}$ & $\mathbf{0 , 8 2}$ & $\mathbf{6 7 , 2 3} \pm \mathbf{0 , 2 0}$ & $\mathbf{0 , 7 4}$
\end{tabular}

Lượng thức ăn thu nhận của vịt tăng dần theo độ tuổi của vịt. Giai đoạn đầu vịt chưa phát triển về khối lượng cơ thể nên lượng thức ăn thu nhận thấp. Giai đoạn sau vịt phát triển về khối lượng cơ thể nên lượng thức ăn thu nhận cũng tăng mạnh. Cụ thể giai đoạn sơ sinh - 3 tuần tuổi lượng tiêu thụ thức ăn trong tuần của con trống là $27,10 \mathrm{~g} / \mathrm{con} /$ ngày và con mái là 26,01 $\mathrm{g} / \mathrm{con} /$ ngày. Giai đoạn từ $18-21$ tuần tuổi lượng tiêu thụ thức ăn trong tuần đạt cao nhất của con trống là $92,17 \mathrm{~g} / \mathrm{con} /$ ngày và con mái là 84,67 g/con/ngày. Lượng thức ăn thu nhận trung bình từ sơ sinh - 21 tuần tuổi của con trống là 71,22 $\mathrm{g} /$ con/ngày và con mái là $67,23 \mathrm{~g} / \mathrm{con} / \mathrm{ngày}$.

\subsubsection{Tiêu tốn thức ăn/l kg tăng khối lương của} vịt trời

Kết quả tiêu tốn thức ăn trên $\mathrm{kg}$ tăng khối lượng của vịt trời thí nghiệm được trình bày tại bảng 3.4.

Bảng 3.4. Tiêu tốn thức ăn/1 kg tăng khối lượng của vịt trời qua các tuần tuổi $(\mathrm{kg})(\mathrm{n}=180)$ 


\begin{tabular}{ccccc}
\hline \multirow{2}{*}{ Tuần tuổi } & \multicolumn{2}{c}{ Trống } & \multicolumn{2}{c}{ Mái } \\
\cline { 2 - 5 } & $\overline{\boldsymbol{x}}_{ \pm} \boldsymbol{m} \overline{\boldsymbol{x}}$ & $\mathbf{C v \%}$ & $\overline{\boldsymbol{x}}_{ \pm} \boldsymbol{m} \overline{\boldsymbol{x}}$ & $\mathbf{C v \%}$ \\
\hline Sơ sinh -3 & $2,43 \pm 0,01$ & 0,71 & $2,48 \pm 0,01$ & 0,56 \\
$3-6$ & $3,85 \pm 0,04$ & 1,82 & $4,03 \pm 0,03$ & 0,83 \\
$6-9$ & $5,49 \pm 0,13$ & 2,21 & $6,41 \pm 0,09$ & 1,07 \\
$9-12$ & $7,24 \pm 0,17$ & 2,77 & $9,53 \pm 0,11$ & 1,35 \\
$12-15$ & $10,90 \pm 0,19$ & 3,01 & $11,14 \pm 0,17$ & 2,08 \\
$15-18$ & $14,01 \pm 0,22$ & 3,12 & $13,73 \pm 0,20$ & 2,61 \\
$18-21$ & $30,79 \pm 0,25$ & 4,04 & $33,03 \pm 0,26$ & 3,12 \\
So $\sinh -\mathbf{2 1}$ & $\mathbf{7 , 4 3} \pm \mathbf{0 , 0 9}$ & $\mathbf{1 , 2 7}$ & $\mathbf{8 , 0 7} \pm \mathbf{0 , 0 6}$ & $\mathbf{1 , 0 9}$ \\
\hline
\end{tabular}

Kết quả bảng 3.4 cho thấy ở tuần đầu thí nghiệm tiêu tốn thức ăn cho $1 \mathrm{~kg}$ tăng khối lượng ở mức thấp (giai đoạn sơ sinh - 3 tuần tuổi của con trống là $2,43 \mathrm{~kg}$, của con mái là $2,48 \mathrm{~kg}$ ). Tiêu tốn thức ăn cho $1 \mathrm{~kg}$ tăng khối lượng tiếp tục tăng mạnh ở các giai đoạn thí nghiệm tiếp theo. Giai đoạn 12 - 15 tuần tuổi của con trống là $10,90 \mathrm{~kg}$ và con mái là $11,14 \mathrm{~kg}$. Giai đoạn $18-21$ tuần tuổi lượng tiêu tốn thức ăn đạt cao nhất của con trống là $30,79 \mathrm{~kg}$ và con mái là $33,03 \mathrm{~kg}$. Tiêu tốn thức ăn cho $1 \mathrm{~kg}$ tăng khối lượng giai đoạn từ sơ sinh - 21 tuần tuổi của con trống là $7,43 \mathrm{~kg}$ và con mái là $8,07 \mathrm{~kg}$.

\subsection{Kết quả khảo sát năng suất và chất luọng} thịt vịt trời tại 21 tuần tuổi

Để đánh giá chất lượng thịt của vịt trời nghiên cứu chúng tôi tiến hành mổ khảo sát với tổng số 18 con (3 mái + 3 trống/ 1 lô thí nghiệm) lúc 21 tuần tuổi, kết quả khảo sát được trình bày ở bảng 3.5.

Bảng 3.5. Kết quả mổ khảo sát vịt trời lúc 21 tuần tuổi $(\mathrm{n}=18)$

\begin{tabular}{lcccc}
\hline \multirow{2}{*}{ Chỉ tiêu } & \multicolumn{2}{c}{ Trống } & \multicolumn{2}{c}{ Mái } \\
\cline { 2 - 5 } & $\overline{\boldsymbol{x}}_{\mathbf{n} \boldsymbol{m} \overline{\boldsymbol{x}}}$ & $\mathbf{C v} \%$ & $\overline{\boldsymbol{x}}_{ \pm \boldsymbol{m}} \boldsymbol{\boldsymbol { \boldsymbol { x } }}$ & $\mathbf{C v} \%$ \\
\hline Khối lượng giết mổ (g) & $1467,22 \pm 10,82$ & 2,64 & $1252,39 \pm 11,48$ & 8,20 \\
Khối lượng thân thịt (g) & $936,11 \pm 9,90$ & 2,59 & $788,00 \pm 10,01$ & 3,42 \\
Tỷ lệ thân thịt (\%) & $63,80 \pm 0,11$ & 0,42 & $62,94 \pm 0,31$ & 1,20 \\
Tỷ lệ thịt đùi (\%) & $19,55 \pm 0,28$ & 0,48 & $20,91 \pm 0,31$ & 1,62 \\
Tỷ lệ thịt ngực (\%) & $28,67 \pm 0,46$ & 0,93 & $30,40 \pm 0,90$ & 1,22 \\
Tỷ lệ thịt đùi + thịt ngực (\%) & $48,23 \pm 0,70$ & 0,57 & $51,30 \pm 1,18$ & 1,65 \\
Tỷ lệ mỡ bụng (\%) & $1,19 \pm 0,08$ & 0,08 & $1,15 \pm 0,12$ & 0,38
\end{tabular}

Tỷ lệ thân thịt của vịt trống là $63,80 \%$ cao hơn $0,86 \%$ so với vịt mái $(62,94 \%)$. So với kết quả nghiên cứu về vịt trời của Nguyễn Đức Cường (2017) có tỷ lệ thân thịt $85,7 \%$ và của Nguyễn Hoàng Thịnh và cs (2018) là 79,15\% thì kết quả của chúng tôi thấp hơn.

Tỷ lệ thịt đùi của vịt trống là 19,55 \% thấp hơn $1,36 \%$ so với vịt mái $(20,91 \%)$. Kết quả này cao hơn so với vịt trời “Anas Supercillosa” của Nguyễn
Đức Cường (2017) có tỷ lệ thịt đùi 14,4 \% và cao hơn so với kết quả của Nguyễn Hoàng Thịnh và cs (2018) (tỷ lệ thịt đùi 10,83\%).

Tỷ lệ thịt ngực của vịt trống là $28,67 \%$ thấp hơn $1,73 \%$ so với vịt mái $(30,40 \%)$. Kết quả này cao hơn so với vịt trời "Anas Supercillosa" của Nguyễn Đức Cường (2017) có tỷ lệ thịt ngực 14,6\% và cao hơn so với kết quả nghiên cứu vịt trời của 
Nguyễn Hoàng Thịnh và cs (2018) (tỷ lệ thịt ngực $15,63 \%)$.

Tỷ lệ thịt đùi + ngực của vịt trống là 48,23\% thấp hơn 3,07\% so với vịt mái (51,30\%).

Tỷ lệ mỡ bụng của vịt trống là $1,19 \%$ cao hơn $0,04 \%$ so với vịt mái $(1,15 \%)$. Kết quả này thấp hơn so với với vịt trời "Anas Supercillosa" của Nguyễn Đức Cường (2017) có tỷ lệ mỡ bụng là
$1,64 \%$ và thấp hơn so với vịt $\mathrm{CV}$ super $\mathrm{M}$ của Lương Tất Nhợ (1994) (tỷ lệ mỡ bụng: 1,65\%).

\subsection{So bộ hạch toán kinh tế của nuôi vịt tròi}

Tất cả các khoản chi từ con giống, thức ăn, thuốc thú $\mathrm{y}$, khấu hao chuồng trại và các khoản thu đều được chúng tôi ghi chép cẩn thận để hạch toán kinh tế của vịt trời thí nghiệm. Kết quả được trình bày tại bảng 3.6 .

Bảng 3.6. Sơ bộ hạch toán kinh tế của nuôi vịt trời

\begin{tabular}{lcccc}
\hline \multicolumn{1}{c}{ Nội dung } & ĐVT & Số lượng & $\begin{array}{c}\text { Đơn giá } \\
\text { (VNĐ) }\end{array}$ & $\begin{array}{c}\text { Thành tiền } \\
\text { (VNĐ) }\end{array}$ \\
\hline 1. Các khoản chi & con & 180 & 30.000 & 5.400 .000 \\
Giống & $\mathrm{kg}$ & 1.832 & 9.000 & 16.488 .000 \\
Thức ăn & con & 180 & 6.000 & 1.080 .000 \\
Thuốc thú y & con & 180 & 2.000 & 360.000 \\
Khấu hao chuồng trại + điện nước & đồng & & & $\mathbf{2 3 . 3 2 8 . 0 0 0}$ \\
Tổng các khoản chi & & & & \\
\hline 2. Các khoản thu & $\mathrm{kg}$ & 240,75 & 135.000 & $\mathbf{3 2 . 5 0 1 . 2 5 0}$ \\
Khối lượng thịt cuối kỳ & & & $\mathbf{9 . 1 7 3 . 2 5 0}$ & \\
\hline
\end{tabular}

\section{Thu nhập hỗn họpp}

Kết quả bảng 3.6 cho thây: Tống chi phí chăm sóc nuôi dưỡng 180 vịt trời trong 21 tuần là 23.328.000 đồng tương ứng với mỗi $\mathrm{kg}$ vịt xuất bán phải chịu chi phí là 129.600 đồng/kg. Theo kết quả thu được từ việc bán đàn vịt trời thì giá $1 \mathrm{~kg}$ vịt trời là 135.000 đồng $/ \mathrm{kg}$ (cao hơn so với giá sản xuất là 5.400 đồng), vậy tổng tiền thu được khi bán đàn vịt là 32.501 .250 đồng. Như vậy, thu nhập hỗn hợp từ bán vịt trời là 9.173 .250 đồng.

Theo Phùng Đức Tiến và cs (2010) thì tổng thu nhập 100 vịt 2 dòng vịt $\mathrm{SD} 1$ và SD2 lần lượt là 1.015.255 đồng và 1.077.082 đồng, vậy kết quả của chúng tôi cao hơn gần 5 lần lý do chênh lệch là do giá thịt vịt thương phẩm chỉ dao động trong khoảng $25.000-50.000$ đồng $/ \mathrm{kg}$ còn giá vịt trời thường dao động từ 135.000 - 150.000 đồng $/ \mathrm{kg}$.

\section{Kết luận và đề nghị}

\subsection{Kết luận}

Từ kết quả nghiên cứu, chúng tôi xin rút ra một số kết luận như sau:
9.173.250

Vịt trời con có lông màu nâu xám, lông cố và ức màu vàng, lưng có chấm vàng đặc trưng, đầu có sọc vàng kéo xuống phía dưới cổ, hai bên mắt có một vệt đen từ mắt kéo dài ra sau, chân có màu đen. Vịt non có tiếng kêu kéc kéc. Vịt trưởng thành có mỏ màu đen, đầu mỏ có vành khuyết màu vàng thân màu xám vằn, lông đuôi màu nâu đen có ánh và viền nâu nhạt, lông cánh ánh xanh. Con trống có đầu to, cổ có 2 sọc trắng, lông cổ dưới màu trắng, hai bên mắt có một vệt đen từ mắt kéo dài ra sau, mắt màu nâu sẫm, lông đuôi vểnh, có vài lông cong và tiếng kêu khẹc khẹc đặc trưng. Vịt mái đầu nhỏ hơn con trống, có mắt màu nâu nhạt, lông đuôi thẳng, hơi cụp xuống và tiếng kêu quạc quạc.

Tỷ lệ nuôi sống của vịt trời cao trên $98 \%$. Khối lượng sơ sinh và 21 tuần tuổi của con trống và con mái lần lượt là: 43,45 - 40,55 và $1.452,21$ $1.264,92 \mathrm{~g} / \mathrm{con}$. Tiêu tốn thức ăn $1 \mathrm{~kg}$ tăng khối lượng từ sơ sinh - 21 tuần tuổi của con trống là 7,43 $\mathrm{kg}$ và con mái là $8,07 \mathrm{~kg}$. Tỷ lệ thân thịt, tỷ lệ thịt đùi + thịt ngực và tỷ lệ mỡ bụng của con trống và con mái lần lượt là 63,80 - 62,94\%; 48,23 - 51,30\% và $1,19-1,15 \%$. 
Hiệu quả kinh tế của mô hình nuôi 180 vịt trời với mức thu nhập hỗn hợp là 9.173.250 đồng cao gấp khoảng 5 lần so với vịt thường.

\section{2. Đề nghị}

Tiếp tục đẩy mạnh mô hình chăn nuôi vịt trời nuôi thịt trên địa bàn tỉnh Ninh Bình và một số tỉnh lân cận nhằm nâng cao về số lượng và chất lượng đàn vịt trời

\section{TÀI LIỆU THAM KHẢO}

1. Nguyen Van Ban (2000), research on some biological characteristics and production features of Co duck, Khaki Campbell and F1 crossbreeds breeding in Thanh Liem, Ha Nam, PhD thesis in Biology, Hanoi University of Education.

2. Nguyen Duc Cuong (2017), "Research on the adaptability of the breed" Mallard "was domesticated in Tran Yen district, Yen Bai province ", scientific research report of Department of Science and Technology of Yen Bai province, p. 30 - 36.

3. Nguyen Thi Minh, Nguyen Duc Trong, Nguyen Thi Thuy Nghia and Dong Thi Quyen (2007), "Research on biological characteristics and production ability of the Zhe Giang duck", Scientific report of livestock institute. p. $62-69$.

4. Luong Tat Nhay (1994), Growth characteristics for meat and duck feathers CV Super $M$ raised in Northern Vietnam, PhD thesis, Vietnam Institute of Agricultural Science and Technology.

5. Nguyen Duc Trong, Nguyen Van Duy, Hoang Van Tieu, Vuong Lan Anh, Nguyen Thi Thuy Nghia, Dong Thi Quyen, Vu Hoang Chung and Hoang Van Truong (2010), "Characteristics of appearance and production capacity of the cross-breed of grass duck and Zhe Giang duck", Scientific report 2010 National Institute of Livestock Production, p. 126 135.

6. Nguyen Hoang Thinh, Tran Bich Phuong and Nguyen Dang Cuong (2018), meat production ability of mallard duck (Anas superciliosa), Publisher: Vietnam Academy of Agriculture, Hanoi p. 39 - 48.

7. Phung Duc Tien, Nguyen Ngoc Dung, Le Thi Nga, Vu Duc Canh, Nguyen Thi Huong, Pham Thi Xuan, Le Thi Cam, Tran Thi Thu Hang, Nguyen Thi Luyen (2010), Select SD ducks bred varieties. Scientific report 2007 National Institute of Livestock Production. Genetic part like pets. Hanoi, 2010.

\section{Study on biological characteristics, production capacity and economic efficiency}

\section{of the eastern spot-billed duck (anas poecilorhyncha zonorhyncha) raised in households in Ninh Binh Province}

Tu Quang Trung, Le Phuong Dung

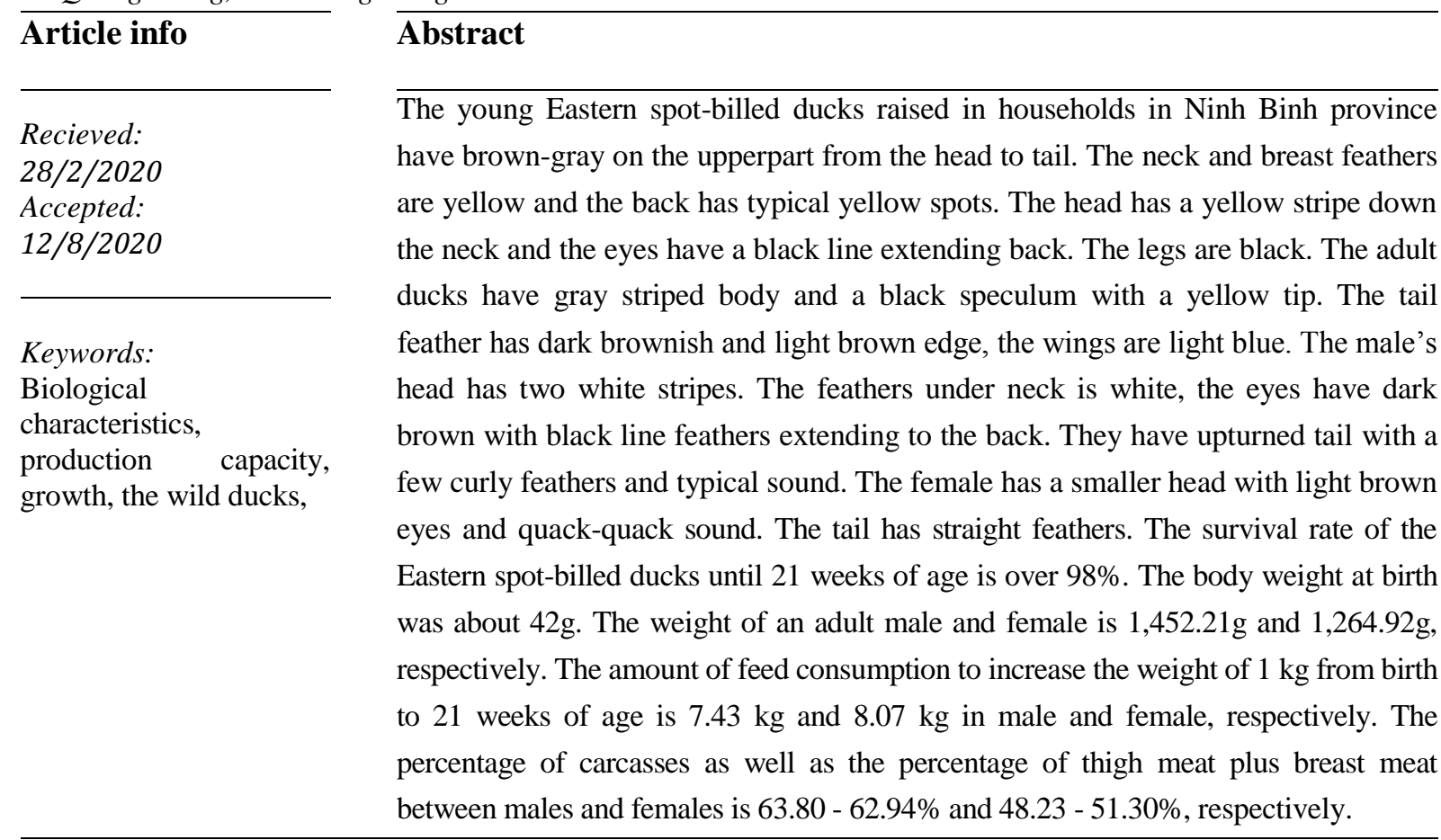

